\title{
LIBERALISASI MASYARAKAT EKONOMI ASEAN 2015: APAKAH KITA PERLU HUKUM PIDANA EKONOMI? (LIBERALIZATION AEC 2015: DO WE NEED ECONOMIC CRIMINAL LAW?)
}

\author{
Hamzah Hatrik \\ Fakultas Hukum Universitas Bengkulu \\ Email: hazetha.asa@gmail.com
}

\begin{abstract}
The liberalization ofthe Asean Economic Community is a process of economic integration free way to apply the principles of an open economy and market oriented. Liberal economic characteristics such as the free flow of goods, free flow of services, free flow of investment, free flow of capital, and the free flow of skilled labor indicate increasing role of corporations. Based on the reality of the negative impacts of corporate activities to maximize profit without limits, then the economics of criminal law is useful to anticipate corporate crime. To improve the functioning ofthe economic criminal law, then the Criminal Code (ius contituendum) there should be special arrangement of corporate criminal liability as a legal person. Based on the proposed conceptual study conclusions and suggestions for formulating the basic corporate criminal sanctions: the lifting of the deed; revocation of business license; restitution; and fines. While the additional punishment: pecabutan certain rights; deprivation of certaingoods; and publication of the decision of the judge.
\end{abstract}

Keywords: liberalization, economic, corporate, criminal law.

\begin{abstract}
ABSTRAK
Liberalisasi Masyarakat Ekonomi Asean merupakan proses integrasi ekonomi bebas hambatan untuk menerapkan prinsip ekonomi terbuka dan berorientasi pada pasar. Karakteristik ekonomi liberal seperti aliran bebas barang, aliran bebas jasa, aliran bebas investasi, aliran modal yang lebih bebas, dan aliran bebas tenaga kerja terampil mengindikasikan peran korporasi makin meningkat. Berdasarkan realitas dampak negatif aktivitas korporasi memaksimalkan profit tanpa batas, maka hukum pidana ekonomi berguna untuk mengantisipasi kejahatan korporat. Untuk meningkatkan fungsi hukum pidana ekonomi, maka dalam KUHP (ius contituendum) harus ada pengaturan khusus tanggung jawab pidana korporasi sebagai person hukum. Berdasarkan kajian konseptual diajukan simpulan dan saran untuk merumuskan sanksi pidana pokok korporasi: pencabutan akta; pencabutan izin usaha; restitusi; dan denda. Sedangkan pidana tambahan: pecabutan hak tertentu; perampasan barang tertentu; dan publikasi putusan hakim.
\end{abstract}

Kata Kunci: liberalisasi, ekonomi, korporasi, hukum pidana.

Hamzah Hatrik, Liberalisasi Masyarakat Ekonomi ASEAN 2015: Apakah Kita Perlu Hukum Pidana Ekonomi? (Liberalization AEC 2015: Do We Need Economic Criminal Law?) 


\section{PENDAHULUAN}

Association South East Asian Nations (ASEAN) eksis sejak Deklarasi Bangkok 8 Agustus 1967. ASEAN didirikan atas dasar pertimbangan bahwa negara-negara di Asia Tenggara mempunyai tanggung jawab untuk memperkuat stabilitas ekonomi dan sosial, menjamin adanya perdamaian dan memajukan pembangunan nasional serta menjamin adanya stabilitas keamanan dari interferensi eksternal dengan segala bentuk manifestasinya. ${ }^{1}$ Deklarasi Bangkok berisi tujuh tujuan ASEAN, antara lain menyatakan: 'Mempercepat pertumbuhan ekonomi, kemajuan sosial serta pengembangan kebudayaan di kawasan ini melalui usaha bersama dalam semangat kesetaraan dan kemitraan untuk memperkokoh landasan bagi masyarakat bangsabangsa Asia Tenggara yang sejahtera dan damai. ${ }^{2}$

Berkelindan dengan tujuan mempercepat pertumbuhan ekonomi ASEAN dan berdasarkan motto "One Vision, One Identity, One Community"3 (Satu Visi, Satu Identitas, Satu Komunitas), maka 7 Oktober 2003 ASEAN menyepakati Declaration of

${ }^{1}$ The Asean Declaration (Bangkok Declaration) Bangkok,http://www.asean. org/news/item/the-asean-declarationbangkok-declaration, diakses Jum'at 19 September 2014.

${ }^{2}$ Second, that the aims and purposes of the Association shall be: To accelerate the economic growth, social progress and cultural development in the region through joint endeavours in the spirit of equality and partnership in order to strengthen the foundation for a prosperous and peaceful community of South-East Asian Nations.

${ }^{3}$ Asean Secretariat, Charter of The Association of Souteast Asian Nations, Jakarta: Asean Secretariat, 2008, hlm. 29. Article 36 "The ASEAN motto shall be: "One Vision, One Identity, One Community" Hamzah Hatrik, Liberalisasi Masyarakat Ekonomi ASEAN 2015: Apakah Kita Perlu Hukum
Pidana Ekonomi? (Liberalization AEC 2015: Do We Need Economic Criminal Hamzah Hatrik, Liberalisasi Masyarakat Ekonomi ASEAN 2015: Apakah Kita Perlu Hukum
Pidana Ekonomi? (Liberalization AEC 2015: Do We Need Economic Criminal Law?)

ASEAN Concord II (Bali Concord II) yang berisi tiga pilar komunitas Asean, yakni ASEAN Security Community(ASC), ASEAN Economic Community (AEC), dan ASEAN Socio Cultural Community (ASCC). ${ }^{4}$ Khusus pilar ASEAN Economic Community (AEC) atau Masyarakat Ekonomi ASEAN (MEA) disepakati bahwa integrasi ekonomi Asean direalisasikan tahun 2020 dengan tujuan menciptakan kawasan ekonomi ASEAN yang stabil, makmur dan berdaya saing tinggi yang memungkinkan aliran bebas barang, jasa, investasi dan aliran modal yang lebih bebas, pembangunan ekonomi yang adil dan mengurangi kemiskinan dan kesenjangan sosial-ekonomi. ${ }^{5}$ Kemudian berdasarkan Cebu Declaration $13 \quad$ Januari 2007 (12 ${ }^{\text {th }} A S E A N$ Summit) realisasiMEAdipercepat tahun 2015. MEA mempunyai empat karakteristik: (1) pasar tunggal dan basis produksi; (2) kawasan ekonomi berdaya saing tinggi; (3) kawasan pembangunan ekonomi merata; dan (4) kawasan yang terintegrasi penuh dengan ekonomi global. 6

${ }^{4}$ Declaration of ASEAN Concord II (Bali Concords II), http://www.asean.org/ news/item/declaration-of-asean-concordii-bali-concord-ii, diakses 19 September 2014.

${ }^{5}$ Declaration of ASEAN Concord II (Bali Concors II) The ASEAN Economic Community is the realisation of the end-goal of economic integration as outlined in the ASEAN Vision 2020, to create a stable, prosperous and highly competitive ASEAN economic region in which there is a free flow of goods, services, investment and a freer flow of capital, equitable economic development and reduced poverty and socioeconomic disparities in year 2020.http://www.asean.org/news/item/ declaration-of-asean-concord-ii-baliconcord-ii, diakses 19 September 2014.

6 Asean Secretariat, Asean Economic Community Blueprint, Jakarta: Asean 
Merujuk empat pilar MEA di atas dapat dipahami bahwa MEA dibentuk atas dasar pandangan positif untuk memajukan pertumbuhan ekonomi komunitas Asean maupun masing-masing negara anggota Asean dengan perbedaan prinsip ekonomi yang dianut. Bagi Indonesia, kebijakan sosial di bidang ekonomi harus mengacu pada amanah Pembukaan Undang-Undang Dasar Negara Republik Indonesia Tahun 1945 (UUD 1945) yang mengamanahkan kepada Pemerintah Negara Indonesia untuk '....melindungi segenap bangsa Indonesia dan seluruh tumpah darah Indonesia dan untuk memajukan kesejahteraan umum,...'7 dengan mengaplikasikan asas perekonomian nasional Indonesia berdasarkan Pasal 33 UUD 1945. Artinya, untuk membumikan MEA yang bersifat liberal di Indonesia, pemerintah dihadapkan pada persoalan kebijakan kesejahteraan sosial (social welfare policy) dan kebijakan perlindungan sosial (social defense policy) untuk mecapai tujuan utama mewujudkan masyarakat adil dan makmur.

Kebijakan kesejahteraan dan perlindungan sosial dalam negara hukum, harus menggunakan hukum merupakan sarana bagi pemerintah untuk menyelenggarakan perlindungan dan kesejahteraan sosial. ${ }^{8}$ Jika dihubungkan dengan realisasi MEA

Secretariat, 2008, hlm. 6. '... the AEC envisages the following key characteristics: ( (a) a single market and production base, (b) a highly competitive economic region, (c) a region of equitable economic development, and (d) a region fully integrated into the global economy.

7 Lihat Undang-Undang Dasar Negara Republik Indonesia Tahun 1945, Pembukaan, Alinea Ke-IV.

8 Persahi, Kerangka Landasan Pembangunan Hukum, Jakarta: Sinar Harapan, 1989, hlm. 14. yang pada hakikatnya adalah penerapan ekonomi liberalistik kapitalistik didekati dengan menggunakan optik hukum, maka persoalan akan berkelindan dengan fungsi hukum pidana ekonomi sebagai sarana mengantisifasi dampak negatif korporat sebagai subjek hukum yang mendominasi pembangunan di bidang ekonomi dan kesejahteraan rakyat.

Dalam konteks dan ruang lingkup realisasi MEA 2015 yang berkarakteristik ekonomi liberal, maka tulisan ini diberi judul 'Liberalisasi MEA 2015: Apakah Kita Perlu Hukum Pidana Ekonomi? Judul tulisan ini didasari pertimbangan dan alasan: Pertama, korporat sebagai subjek hukum menjadi mitra utama pemerintah dalam pembangunan ekonomi. Kedua, pasar terbuka atau perdagangan terbuka era MEA memunculkan persaingan usaha lebih terbuka yang berdampak tidak hanya merugikan korporat pesaing, tetapi jugakepentingan negara, masyarakat maupun individu dengan bentuk kerugian berskala luas. Ketiga, dampak negatif aktivitas korporat, tidak hanya masuk domain hukum perdata (ekonomi) dan hukum administrasi, tetapi dalam kasus tertentu masuk domain hukum pidana. Ke-empat, kebijakan kriminal menanggulangi kejahatan korporat (corporate crime) dengan menggunakan hukum pidana masih menjadi perdebatan teoretik maupun praktik berdasarkan argumentasi societas delinquere non potest dan sanksi hukum pidana sebagai sarana the last resort.

Berdasarkan pertimbangan dan alasan di atas dan sesuai tema seminar nasional Dosen BKS PTN Fakultas Hukum Wilayah Barat yang diselenggarakan Fakultas Hukum Universitas Bengkulu 2014, maka tulisan yang berjudul 'Liberalisasi MEA 2015: Apakah kita memerlukan hukum

Hamzah Hatrik, Liberalisasi Masyarakat Ekonomi ASEAN 2015: Apakah Kita Perlu Hukum Pidana Ekonomi? (Liberalization AEC 2015: Do We Need Economic Criminal Law?) 
pidana ekonomi?' Tulisan yang sangat sederhana ini akan mengartikulasikan bahan diskusi dengan sistematika sebagai berikut: (1) liberalisai ekonomi dan prinsip perekonomian Indonesia; (2) Dampak Korporasi Sebagi Subjek Hukum Ekonomi; dan (3) Hukum Pidana Ekonomi Sebagai Sarana Hukum Alternatif.

\section{PEMBAHASAN}

\section{Liberalisasi Ekonomi dan Prinsip Perekonomian Indonesia}

Terminologi liberal merujuk cara pandang atau cara berpikir yang mengutamakan kebebasan dan kesetaraan secara alamiah dalam konteks hukum alam. Lock pernah mengatakan bahwa hukum'...teaches all mankind...that being all equal and independent, no one ought to harm another in his life, health, liberty, or possessions....'9 Jika dihubungkan dengan pemerintahan suatu negara, maka pemerintah dalam penyelenggaraan negara tidak boleh melanggar kebebasan dan kesetaraan hak alami setiap orang seperti kebebasan berusaha dan berniaga.

Berdasarkan terminologi liberal, maka liberalisasi berarti proses atau usaha untuk menerapkan kehidupan ekonomi liberalisme. Proses pembumian ekonomi liberal dapat dipahami melalui Cetak Biru MEA (AEC Blueprint) yang menjadikan ASEAN sebagai pasar tunggal dan basis produksi yang mencakup: (i) aliran bebas barang, (ii) aliran bebas jasa, (iii) aliran bebas investasi, (iv) aliran modal yang lebih bebas, dan (v) aliran bebas tenaga kerja terampil. ${ }^{10}$ Kelima sektor tersebut satu

9 John Lock (Edited by C. B.

Macpherson), Second Treatise of

Government, Cambridge: Hackett

Publishing Company, Inc., 1980, hlm. 9.

${ }^{10}$ ASEAN Secretariat, Asean Economic

Community Blueprint,Loc. Cit.

Hamzah Hatrik, Liberalisasi Masyarakat Ekonomi ASEAN 2015: Apakah Kita Perlu Hukum Pidana Ekonomi? (Liberalization AEC 2015: Do We Need Economic Criminal Law?) dengan yang lainnya saling berkait dan berpengaruh. Di samping kelima sektor itu, termasuk pula prioritas integrasi sektor dan kerjasama di bidang pangan, pertanian, dan kehutanan. ${ }^{11}$

Aliran bebas barang merupakan upaya mewujudkan pasar tunggal dan basis produksi yang menjadikan bagian mata rantai pasokan global. Aliran bebas barang dan jasa sebenarnya telah teraktualisasi melalui AFTA (Asean Free Trade Area) dengan kesepakatan penghapusan tarif dan non-tarif. Sedangkan yang berkaitan dengan lintas bebas barang dilakukan melalui integrasi kepabean dalam rangka memfasilitasi perdagangan terbuka yang bertujuan memudahkan integrasi ASEAN menuju pasar tunggal dan basis produksi untuk barang, jasa, dan investasi.12 Aliran bebas sektor jasa bertujuan mewujudkan bebas hambatan bagi pemasok jasa ASEAN dalam bidang penyediaan jasa lintas negara seperti jasa transportasi, keuangan, dan profesional. Dalam hal ini liberalisasi akan dilakukan kebijakan tarif yang disesuaikan dengan tarif domestik negara anggota ASEAN. Khusus untuk liberalisasi jasa profesional dilakukan melalui kebijakan pengakuan kualifikasi profesional.

Liberalisasi ekonomi pada intinya adalah proses menghilangkan hambatan di bidang ekonomi. Misalnya, liberalisasi perdagangan jasa berkaitan dengan permbukaan akses pasar dan perlakuan nasional untuk setiap mode of supply. Hambatan yang memengaruhi akses pasar antara lain adalah pembatasan jumlah penyedia jasa, volume transaksi, jumlah

${ }^{11}$ ASEAN Secretariat, Asean Economic Community Blueprint,Loc. Cit.

${ }^{12}$ Asean Secretariat, Asean Economic Community Blueprint, Op. Cit., hlm. 10. 
operator, jumlah tenaga kerja, bentuk hukum dan kepemilikan modal asing. Sedangkan hambatan perlakuan nasional antara lain bentuk peraturan yang diskriminatif seperti persyaratan pajak, kewarganegaraan, jangka waktu menetap, perizinan, standardisasi dan kualifikasi, kewajiban pendaftaran serta batasan kepemilikan properti dan lahan. ${ }^{13}$ Dalam kaitan menjadi relevan dikemukakan contoh AFAS (Asean Framework Agreement Service) mengenai penghilangan hambatan penyedia jasa kepada kepada pengguna jasa (mode of suppiy) dalam perdagangan jasa:

Mode 1 (Cross-border supply):jasa yang diberikan langsung penyedia jasa luar negeri kepada pengguna di dalam negeri. Contoh: pertimbangan hukum diberikan oleh pengacara di luar negeri melalui surat atau telepon.

Mode 2 (Consumption abroad): jasa diberikan penyedia jasa di luar negeri kepada konsumen domestik setelah konsumen berpindah secara fisik ke negara penyedia jasa. Contohnya pasien Indonesia berobat ke rumah sakit di Singapura.

Mode 3 (commercial presence): jasa yang disediakan dengan kehadiran penyedia jasa dari luar negeri kepada konsumen di negara konsumen. Contoh: pendirian rumah sakit milik Singapura di Indonesia.

Mode 4 (Movement of individual service providers): penyediaan jasa langsung berupa tenaga kerja asing yang memiliki keahlian

${ }^{13}$ Sjamsul Atifin, Rizal A. Djaafara, dan Aida S. Budiman, Masyarakat Ekonomi Asean (MEA) 2015: Memperkuat Sinergi ASEAN di Tengah Kompetisi Global, Jakarta: Elex Media Komputindo, 2008, hlm. 129. tertentu kepada konsumen di negara konsumen, contohnya dokter Singapura melakukan praktik di Indonesia. ${ }^{14}$

Contoh di atas sengaja dipinjam untuk mengemukakan bahwa membumikan liberalisasi ekonomi akan menyangkut kompleks persoalan yang multiversitas khususnya mengenai 'aliran bebas investasi dan aliran modal yang lebih luas'15 dalam konteks mengimplementasikan asas kekeluargaan dan demokrasi ekonomi yang dirumuskan dalam Pasal 33 UUD 1945yang menyatakan sebagai berikut:

(1) Perekonomian disusun sebagai usaha bersama berdasar atas asas kekeluargaan. ${ }^{16}$

(2) Cabang-cabang produksi yang penting bagi negara dan yang menguasai hajat hidup orang banyak dikuasai oleh negara. ${ }^{17}$

\footnotetext{
${ }^{14}$ Ibid., hlm. 128.

15Asean Secretariat, Asean Economic
} Community Blueprint,Op. Cit., hlm. 12-14.

16 Asas kekeluargaan masih menjadi perdebatan antar ekonom. Disatu sisi ada ekonom yang mempertahankan asas ekonomi kekeluargaan untuk menentang liberalisme, sedangkan disisi lain ada ekonom yang menganut neoliberali hendak menghapuskan asas ekonomi kekeluargaan dari Pasal 33 UUD 1945.

17 Frasa ‘...dikuasai oleh negara' juga dapat memunculkan tafsir yang berbeda yang mengakibatkan cabang-cabang produksi yang penting dan menguasai hajat hidup orang banyak diserahkan penguasa penganut model ekonomi neoliberal kepada swasta atau para investor asing mengeksploitasi kekayaan yang terkandung di bumi dan air dan kekayaan alam Indonesia untuk menggalikan keuntungan. Padahal arti '...dikuasai oleh negara' dalam Pasal 33 ayat (2) dan Pasal 33 ayat (3) UUD 1945 merupakan: "antitesa terhadap model ekonomi neoliberal sekarang, dimana cabang-cabang produksi yang penting, termasuk layanan publik yang sifatnya

Hamzah Hatrik, Liberalisasi Masyarakat Ekonomi ASEAN 2015: Apakah Kita Perlu Hukum Pidana Ekonomi? (Liberalization AEC 2015: Do We Need Economic Criminal Law?) 
(3) Bumi dan air dan kekayaan alam yang terkandung di dalamnya dikuasai oleh negara dan dipergunakan untuk sebesarbesar kemakmuran rakyat.

(4) Perekonomian nasional diselenggarakan berdasar atas demokrasi ekonomi ${ }^{18}$ dengan prinsip kebersamaan, efisiensi berkeadilan, berkelanjutan, berwawasan lingkungan, kemandirian, serta dengan menjaga keseimbangan kemajuan dan kesatuan ekonomi nasional.

dasar, diserahkan kepada swasta dan menjadi objek menggali keuntungan." $<$ http://m.ber-

dikarionline.com/editorial/20111007/tingg alkan-neoliberalisme-kembali-ke-pasal-33uud-1945.html>

18 Sebelum amandemen UUD 1945, Pasal 33 diberikan penjelasan: 'Dalam Pasal 33 tercantum dasar demokrasi ekonomi, produksi dikerjakan oleh semua, untuk semua di bawah pimpinan atau penilikan anggota-anggota masyarakat. Kemakmuran masyarakatlah yang diutamakan, bukan kemakmuran orangseorang. Sebab itu perekonomian disusun sebagai usaha bersama berdasar asas kekeluargaan. Bangun perusahaan yang sesuai dengan itu ialah koperasi.

Perekonomian berdasar atas demokrasi ekonomi, kemakmuran bagi semua orang! Sebab itu cabang-cabang produksi yang penting bagi Negara dan yang menguasai hidup orang banyak harus dikuasai oleh Negara. Kalau tidak, tampuk produksi jatuh ke tangan orang-seorang yang berkuasa dan rakyat yang banyak ditindasinya.

Hanya perusahaan yang tidak menguasai hajat hidup orang banyak boleh ada ditangan orang-seorang.

Bumi dan air dan kekayaan alam yang terkandung dalam bumi adalah pokok-pokok kemakmuran rakyat. Sebab itu harus dikuasai oleh negara dan dipergunakan untuk sebesar-besar kemakmuran rakyat.

Hamzah Hatrik, Liberalisasi Masyarakat Ekonomi ASEAN 2015: Apakah Kita Perlu Hukum Pidana Ekonomi? (Liberalization AEC 2015: Do We Need Economic Criminal Law?)
(5) Ketentuan lebih lanjut mengenai pelaksanaan pasal ini diatur dalam undangundang.

Pasal 33 UUD 1945 terbuka untuk ditafsirkan berdasarkan optik ekonom progressif maupun ekonom proneoliberalisme. Realitas menunjukkan kepada kiprah neoliberal melalui korporasi (corporation), Free Trade Area, join venture dan beragam kebijakan dalam bentuk regulasi. Implementasi neoliberal di Indonesia bermula sejak era orde baru melalui privatisasi ekonomi, pasar terbuka, serta pengelolaan sektor sumber daya alam. Misalnya hasil mineral dan tambang dikelola oleh korporasi seperti Caltex, Exxon Mobile, ConocoPhillips, dan Chevron Corporation di sektor migas. Disektor tambang dapat disebut Freeport dan Newmont Minahasa Raya.

Free Trade Area (FTA) seperti pembukaan zona ekonomi Batam, Bintan, serta zona integrasi Sijori (Singapura-Johor-Riau) yang berganti nama menjadi Indonesia-MalaysiaSingapura Growth Triangle (IMS-GT) merupakan bentuk zona ekonomi bebas. Batam dan Bintan menjadi basis manufaktur perusahaan multi-nasional dari negara-negara seperti Amerika Serikat, Deutch, Taiwan, Jepang, Australia dan Bahama, serta Singapura. ${ }^{19}$ Dampak FTA melemahkan sektor mikro usaha ekonomi rakyat karena tidak mampu bersaing dengan produk-produk luar negeri.

Regulasi dapat menjadi pintu masuk membumikan liberalisasi ekonomi di Indonesia melalui realisasi

\footnotetext{
${ }^{19}$ Formation of SIJORI Growth

Triangle is announced,

http://eresources.nlb. gov.sg/history/events/bd4d0374-63ae49fe-95c8-2210b3b0ac59, diakses 24 September 2014.
} 
MEA 2015. Hal ini dapat dipahami melalui produk undang-undang ekonomi yang bernuansa liberal seperti Undang-Undang Penanaman Modal Asing, Undang-Undang Migas, Peraturan Pemerintah Nomor 2 tahun 2008 Tentang Kehutanan merupakan produk hukum berisi muatan ekonomi liberal yang mengakibatkan kerusakan alam akibat eksploitasi secara massive oleh korporat-korporat asing.

Berdasarkan

pemahaman

liberalisasi ekonomi dan prinsip perekonomian Indonesia yang diartikulasikan di atas, maka persoalan lebih lanjut adalah dampak negatif peran korporasi sebagai subjek hukum ekonomi yang akan mendominasi pasar tunggal dan basis produksidi era pemberlakuan MEA 2015.

\section{Dampak Korporasi Sebagai Subjek Hukum Ekonomi}

Keberadaan korporasi sebagai subjek hukum dalam kehidupan manusia secara universal telah menjadi suatu keniscayaan, karena korporasi merupakan cermin karakteristik manusia yang menyandang beragam sebutan antara lain homo socius, homo economicus, homo sapien, homo faber bahkan manusia menyandang sebutan homo homini lupus. Sebutan demikian menunjukkan manusia mempunyai potensi serba dimensi ${ }^{20}$ baik dalam arti positif maupun negatif.

Homo socius dalam pandang Ibnu Khaldun bahwa manusia mempunyai kecenderungan bekerja sama sebagai hasil the natural dispotition of human beings yang berfungsi untuk memenuhi kebutuhan manusia. ${ }^{21}$ Homo sapien memahami manusia sebagai makhluk berpikir yang mampu menciptakan

20 M. Dawam Rahardjo, Insan Kamil Konsepsi Manusia Menurut Islam, Jakarta: Grafiti Pers, 1985, hlm. 129.

${ }^{21}$ Ibid., hlm. 159. ilmu pengetahuan dan teknologi karena keingintahuan manusia tentang segala sesuatu termasuk dirinya sendiri. Dengan akal pikiran yang dilengkapi dengan susunan anatomi tubuh terbaik, manusia tidak hanya pengguna alat tetapi mampu menciptakan alat (homo faber). ${ }^{22}$ Beragam alat sebagai wujud teknologi hasil sains merupakan bentuk praktik know-how yang menghasilkan barang dan jasa untuk kebutuhan manusia. Oleh karena itu teknologi berkait erat dengan kegiatan dan organisasi manusia yang berhubungan dengan produksi, distribusi, dan konsumsi barangbarang dan jasa. ${ }^{23}$

Keberagaman potensi manusia yang diartikulasikan memahamkan bahwa korporasi sebagai subjek hukum merupakan hasil pemikiran manusia yang membentuk suatu organisasi di bidang ekonomi, politik, dan sosial kemanusiaan. Jika dihubungkan dengan MEA yang terdiri dari sejumlah negara yang mengadakan kerjasama di bidang ekonomi, maka MEA adalah korporasi. Negara-negara yang membentuk MEA adalah juga korporasi. Dalam hal ini Friedmann mengatakan: 'The state alone, though itself a juristic personality, is placed on the same level as individual. Its personality is really beyond question, and it bestows or withdraws legal personality on or from other groups and associations with its jurisdiction as an attribute of its sovereignty.'24

Realitas peran dan dampak korporasi sebagai subjek hukum bentukan negara yang beraktivitas di

22 The Liang Gie, Pengantar Filsafat Teknologi, Yogyakarta: Andi, 1996, hlm. iii.

23 M. Dawam Rahardjo, Loc., Cit.

24 Wolfgang Friedmann, Legal Theory, London: Stevens \& Sons Limited, 1949, hlm. 361.

Hamzah Hatrik, Liberalisasi Masyarakat Ekonomi ASEAN 2015: Apakah Kita Perlu Hukum Pidana Ekonomi? (Liberalization AEC 2015: Do We Need Economic Criminal Law?) 
bidang ekonomi dapat dicermati dari sisi positif dan negatif. Sisi positif dikemukakan Clarkson dan Hartley dengan optik kebutuhan masyarakat. Dikatakan oleh Clarkson bahwa 'To large extend companies provide the food we eat, the water we drink, the necessities and luxuries of everyday living,'25 sedangkan Hartley mengatakan:

Millions of people are employed by corporations and regard them as their providers. Many young people aspire to become corporate employees. Corporations produce the seemingly endless range of products we purchase and consume, and they sponsor many of the forms of entertainment (especially television) we enjoy. They are also principal sponsors of pioneering research in many fields. Corporations are important benefactors of a large number of charities, public events, institutions of higher learning...26

Pandangan Clarkson dan Hartley bersesuaian dengan klaim korporasi yang menyatakan bahwa praktik bisnis tidak hanya beroperasi untuk kepentingan para pemegang saham, tetapi juga untuk kemaslahatan pihak stakeholders seperti pekerja, komunitas lokal, pemerintah, konsumen, dan lingkungan hidup. Oleh sebab itu, atas nama korporasi para pengusaha mengklaim bahwa korporasi tampil sebagai subjek hukum yang berman-

${ }^{25}$ C.M.V.Clarkson,

Corporate Culpability Web Journal of Current Legal Issues in association with Blackstone Press Ltd. <cmvc1@leicester.ac.uk> diakses 24 September 2014.

${ }^{26}$ Richard D. Hartley, Corporate Crime: A Reference Handbook Contemporary World Issues, Santa Barbara-California: ABCCLIO, Inc., 2008, hlm. 12.

Hamzah Hatrik, Liberalisasi Masyarakat Ekonomi ASEAN 2015: Apakah Kita Perlu Hukum Pidana Ekonomi? (Liberalization AEC 2015: Do We Need Economic Criminal Law?) faat dan mulia bagi manusia, dan menolak kecaman terhadap korporasi.

Sisi negatif keberadaan korporasi yang dikecam karena korporasi berperilaku buruk dapat dicermati melalui stigma yang dilekatkan kepada korporasi maupun pengelolanya. E.A. Ross yang menjelaskan dosa korporasi (corporate sinning) menyandangkan sebutan "The Criminaloid"27 sedangkan Edwin H. Sutherland melekatkan sebutan "White Collar Crime."28 Stigma lain diberikan Albert Morris menyebut korporasi sebagai "criminal of the upperworld" 29 dan Charles R. Henderson memberikan sebutan "educated criminal." 30

Ross menjelaskan keterhubungan perilaku kriminal dengan persoalan hukum dengan ungkapan: The lawmaker may make their misdeeds crimes, but, so long as morality stands stock-still in the old tracks, they escape both punishment and ignominy...The criminaloids... distance their more scrupulous rivals in business and politics and reap an uncommon worldly prosperity. ${ }^{31}$

Stigma yang mengecam perilaku korporasi dikemukakan Clarkson bahwa korporasi mempunyai kewajiban

27 Edward Alsworth Ross, Sin and Society: An Analysis of Latter-Day Iniquity, Boston-New York:Houghton Mifflin Company, 1907, hlm.48

28Edwin Hardlin Sutherland and Donald Ray Cresswy, Criminologi, Tenth Edition, Philadelphia-New York-San JoseToronto: J.B. Lippincott Company, 1978, hlm. 44.

29 Gilbert Geis, White-Collar Crime: The Offenders in Business and Professions, New Jersey, Prentice Hall, 2007, hlm. 34 30 J.E. Sahetapy, Kejahatan Korporasi, Jakarta: Eresco, 1994, hlm. 11. 31 Edward Alsworth Ross, Op. Cit., hlm.49 
'...not to harm or injure others in society without justification,...companies...not to poison our water and food, not to pollute our rivers, beaches and air, not to allow their workplaces to endanger the lives and safety of their employees and the public, and not to sell commodities, or provide transport, that will kill or injure people. ${ }^{32}$ Sedangkan, Hartley mengatakan 'Corporate exploitation of the citizenry and the workforce in society is not a shock, given the fact that profits are the main objective of the corporation. Stockholders and managers alike have a general interest in maximizing profits at the expense of others.'33

Berkelindan dengan pernyaataan Clarkson dan Hartley, Gobert dan Punch menyebutkan kejahatan korporat modern meliputi:

'price-fixing, stock market manipulation, insider trading, anticompetitive market manipulations, the formation of illegal cartels, the manufacture of highly dangerous products, the pollution of the environment, transgressions of health and safety rules in the work place (often leading to death and serious injury), false or misleading advertising, consumer fraud, racial and gender discrimination and other related employment offences, bribery, fiscal offences and industrial espionage. ${ }^{34}$

32 C.M.V.Clarkson, Corporate Culpability Web Journal of Current Legal Issues in association with Blackstone Press Ltd. <cmvc1@leicester.ac.uk> diakses 24 September 2014.

33 Richard D. Hartley, Op. Cit., hlm. 13.

34James Gobert dan Maurice Punch, Rethinking Corporate Crime, Dayton-OhioUSA: Butterworths Lexis Nexis, 2003, hlm. 8-9.

Hamzah Hatrik, Liberalisasi Masyarakat Ekonomi ASEAN 2015: Apakah Kita Perlu Hukum Pidana Ekonomi? (Liberalization AEC 2015: Do We Need Economic Criminal Law?)
Contoh perilaku negatif korporasi yang dikemukakan Clarkson, Hartley, serta Gobert dan Punch telah menjadi realitas di Indonesia seperti kasus semburan lumpur di Sidoarjo, kasus Newmonth Minahasa Raya, dan kasus Freeport. Demikian pula kasus kecelakaan transportasi darat dan udara; perilaku korporasi membohongi publik dan persaingan usaha yang tidak sehat melalui iklan di media tayang siar, serta lain-lain kasus yang melibatkan aktivitas bisnin korporasi.

Belajar dari kasus-kasus korporasi yang bersifat merugikan dan kecenderungan dominasi korporasi dalam konteks realisasi MEA 2015 yang bernuansa ekonomi liberal, maka diskusi lebih lanjut akan menyangkut jawaban: Apakah kita memerlukan hukum pidan ekonomi? Pertanyaan ini diajukan atas dasar pertimbangan bahwa harmonisasi antar sistem hukum merupakan hal yang urgen, khususnya mengenai keberadaan dan kapasitas korporasi sebagai subjek hukum ekonomi yang melanggar hukum yang diancam dengan sanksi pidana.

\section{Hukum Pidana Ekonomi Sebagai Sarana Hukum Alternatif}

Kitab Undang-undang Hukum Pidana (KUHP) sebagai hukum pidana umum yang menjadi payung hukum di luar KUHP, belum mengakui person hukum sebagai subjek tindak pidana, karena secara historis KUHP dibentuk berdasarkan 'konsep dasar suatu tindak pidana hanya dapat dilakukan oleh person alamiah'35 yang tersurat dalam Pasal 59 KUHP: 'Dalam hal-hal dimana karena pelanggaran ditentukan

${ }^{35}$ Muladi, Demokratisasi, Hak Asasi Manusia, dan Reformasi Hukum di Indonesia, Jakarta: The Habibie Center, 2002, hlm. 157 
pidana terhadap pengurus, anggotaanggota badan pengurus atau komisaris-komisaris, maka pengurus, anggota badan pengurus atau komisaris yang ternyata tidak ikut campur melakukan pelanggaran tidak dipidana.' Rumus ini tersurat dan tersirat dasar merumuskan tanggung jawab person hukum dalam KUHP di masa datang (ius constituendum).

Pengaturan pertanggungjawaban pidana korporasi sebagai person hukum menjadi perhatian khusus masyarakat internasional sejak Kongress PBB Ke-7 tentang The Prevention of Crime and The Treatment of Offenders di Milan-Itali 1985. Dalam Guiding Principles for Crime Prevention and Criminal Justice in the Context of Development and a New International Economic Order, terutama yang berkaitan dengan crime prevention and a new international economic order terdapat keputusan kongress mengenai issue of corporate responsibility yang dirumuskan dalam redaksi:

Due consideration sholud be given by Member States to making criminally responsible not only those persons who have acted on behalf of an institution, corporation or enterprise, or who are in policy-making of executive capacity, but also the institution, corporation or enterprise itself, by devising appropriate measure that would prevent or sanction the furtherance of criminal activities. 36

Kesadaran

mempertanggungjawabkan person hukum dalam hukum pidana tercermin

36 United Nation Publication, A/Conf. 121/22/Rev.1. Seventh United Nations Congress On The Prevention of Crime and The Treatment of Offenders, Millan, 26 August-6 September 1985, United Nations Report Prepared by Secretariat, New York, $1986 t$.

Hamzah Hatrik, Liberalisasi Masyarakat Ekonomi ASEAN 2015: Apakah Kita Perlu Hukum Pidana Ekonomi? (Liberalization AEC 2015: Do We Need Economic Criminal Law?) dalam hukum pidana ekonomi yang diatur dalam Undang-Undang Nomor 7/Drt. Tahun 1955 Tentang Pengusutan, Penuntutan dan Peradilan Tindak Pidana Ekonomi (dalam tulisan ini disebut hukum pidana ekonomi), Pasal 15 ayat (1):

Jika suatu tindak pidana ekonomi dilakukan oleh atau atas nama suatu badan hukum, suatu perseroan, suatu perserikatan orang atau suatu yayasan, maka tuntutan pidana dilakukan dan hukuman pidana serta tindakan tata tertib dijatuhkan, baik terhadap badan hukum, perseroan, perserikatan atau yayasan itu, baik terhadap mereka yang memberi perintah melakukan tindak-pidana ekonomi itu atau yang bertindak sebagai pemimpin dalam perbuatan atau kelalaian itu, maupun terhadap kedua-duanya. 37

Realitas menunjukkan putusan pengadilan yang menjatuhkan pidana terhadap korporasi, masih langka. Kenapa demikian? Apa penyebabnya? Banyak jawaban dengan argumentasi sebagai dasar kebenaran masingmasing yang terus didebatkan. Debat mengenai tanggung jawab pidana korporat (corporate criminal liability)secara umum didasari alasan Gilbert Geis, bahwa:

The core question is this: Can a corporation commit a crime? Some insist that the answer should be no. They argue that a corporation is an inanimate entity. It has no mind, no will, and no power to act except through the behavior of people who are in charge of it and those who work for it. But the answer in the law that prevails in the United States is

37Indonesia, Undang-Undang Nomor 7/Drt. Tahun 1955 Tentang Pengusutan, Penuntutan dan Peradilan Tindak Pidana Ekonomi. yang hampir sama seperti ungkapan 
yes. A corporation may be convicted in a criminal court for acts that violate the penal law of the jurisdiction in which it is tried. 38

Tulisan Geis di atas dipinjam untuk menegaskan jika penegak hukum yang memegang teguh paradigma lama berdasarkan prinsip 'societas delinquren non-potest' yang dianut KUHP diperkuat dengan menempatkan sanksi pidana pada 'the last resort dan asas hukum lex specialis derogat lex generalis cenderung hampir terabaikan, maka pemidanaan korporasi hanya sebatas rumusan dalam undang-undang. Artinya, hukum pidana ekonomi hanya statutory dormancy ${ }^{39}$ akibat pengaruh paradigma lama dan pandangan yang memahami Undang-Undang Tindak Pidana Ekonomi dari perspektif hukum perekonomian memuat hukum administrasi, sehingga penegakan hukum perekonomian dilakukan dengan sistim sanksi hukum administratif." 40 Keadaan demikian mengisyaratkan formulasi tanggung jawab person hukum sebagai subjek tindak pidana dalam KUHP menjadi urgen dalam upaya mewujudkan tanggung jawab negara memberikan perlindungan kepentingan sosial terhadap aktivitas korporasi mengejar profit dengan ambisi tanpa batas dengan cara-cara mengabaikan hukum yang berdampak kerugian berskala luas. Dalam hal ini Box menegaskan prioritisasi profit merupakan tujuan

38 Lawrence M. Salinger (Editor), Encyclopedia of White-collar and Corporate Crime Vol 1, California: Sage Publications Ltd., 2005, hlm. 211.

Permasalahan $\begin{aligned} & \text { Hanitijo } \\ & \text { Hukum }\end{aligned} \begin{array}{r}\text { Soemitro, } \\ \text { Dalam }\end{array}$
Masyarakat, Bandung: Alumni, 1984, hlm.
$64 . \quad 40$ Sudarto, Hukum dan Hukum Pidana, Bandung: Alumni, 1986, hlm. 76. organisasional yang memotivasi korporasi melakukan aktivitas mencari dan mengejar target sukses tanpa mematuhi aturan (anomie of success) yang kontradiksi dengan kebutuhan atau kepentingan competitors, State, employees, consumers, public. ${ }^{41}$

Berdasarkan realisasi MEA 2015 yang pada hakikatnya merealisasikan paham ekonomi liberal yang didominasi korporasi dan dalam rangka mengantisipasi kejahatan korporat yang diartikulasikan di atas, makahukum pidana ekonomi sudah saatnya didayagunakan dalam penanggulangan tindak pidana korporasi. Untuk itu badan legislatif dalam pembahasan RUU-KUHP perlu mempertimbangkan pengaturan secara tegas tanggung jawab pidana person hukum sebagai subjek tindak pidana dan pengaturan jenis-jenis pidana yang disesuaikan dengan karakteristik person hukum dalam bab tersendiri.Hal ini didasari pemikiran bahwa korporasi merupakan person hukum sebagai subjek hukum bentukan hukum berdasarkan konstruksi hasil pemikiran filsafat, sehingga penerapan tanggung jawab pidana dan jenis pidana untuk korporasi tidak disamakan dengan pertanggungjawaban pidana dan jenis pidana yang diterapkan terhadap person alamiah. Untuk itu pula, badan legislatif perlu memperhatikan perkembangan teoretis mengenai tanggung jawab pidana korporat.

Berdasarkan perkembangan teoretis doktrinal mengenai tanggung jawab pidana korporasi dapat ditegaskan bahwa doktrin vicarious liability merupakan dasar untuk menentukan korporasi sebagai subjek yang bertanggung jawab yang identik dengan teori identifikasi dan teori

41 Steven Box, Power Crime and Mystification, London-New York: Routledge, 2003, hlm. 64.

Hamzah Hatrik, Liberalisasi Masyarakat Ekonomi ASEAN 2015: Apakah Kita Perlu Hukum Pidana Ekonomi? (Liberalization AEC 2015: Do We Need Economic Criminal Law?) 
organik. Sedangkan strict liabilty merupakan doktrin teoretis menerapkan tanggung jawab tanpa harus membuktikan unsur kesalahan berdasarkan doktrin res ipsa loquitur. Di samping itu, pendekatan penerapan tanggung jawab pidana korporasi sebagai subjek tindak pidana telah tersirat dalam doktrin penyertaan (deelneming, participation) yang identik dengan konsep pelaku fungsional sebagai paradigma baru dalam hukum pidana.

Sesuai karakteristik korporasi sebagai person hukum, maka badan legislatif perlu mempertimbangkan: Pertama, perumusan pidana pokok korporasi: Revokasi akta korporasi;42 Revokasi izin usaha; 43 Restitusi; 44 Denda. Kedua, perumusan pidana tambahankorporasi:45 pencabutan hakhak tertentu; perampasan barangbarang tertentu; pengumuman putusan hakim. Ketiga, perumusan sanksi tin-

42 Setara dengan pidana mati yang diterapkan kepada person alamiah.

43 Setara dengan pidana penjara dan kurungan pada hakikatnya pembatasan kemerdekaan bergerak. Bagi korporasi adalah pembatasan kebebasan menjalankan aktivitas bisnis merupakan bentuk pembatasan kemerdekaan.

44 Pidana restitusi merupakan bentuk kompensasi yang harus dibayarkan korporasi kepada korban sesuai jumlah taksiran kerugian korban akibat yang disebabkan oleh aktivitas korporasi. Sedangkan denda dibayarkan untuk negara.

${ }^{45}$ Ketiga jenis pidana merupakan adaptasi pidana tambahan Pasal 10 KUHP. Pencabutan hak tertentu seperti larangan mengikuti kompetisi mendapat hak mengerjakan suatu proyek pembangunan. Perampasan barang tertentu dapat dilakukan dengan menyita aset korporasi. Pengumuman putusan hakim melalui media cetak atau media tayang siar atas biaya korporasi merupakan bentuk shock therapy untuk mencegah potensi korporasi lain melakukan tindak pidana.

Hamzah Hatrik, Liberalisasi Masyarakat Ekonomi ASEAN 2015: Apakah Kita Perlu Hukum Pidana Ekonomi? (Liberalization AEC 2015: Do We Need Economic Criminal Law?) dakan: perbaikan akibat tindak pidana korporasi; memenuhi kewajiban hukum adat; dan penempatan korporasi di bawah pengampuan (guardianship).

\section{PENUTUP}

Bertalian dengan fokus masalah yang tercermin melalui judul tulisan ini dan berdasarkan kajian konseptual teoretis serta realitas dampak negatif aktivitas korporasi mempriotaskan profit dengan mengabaikan kepentingan publik diajukan simpulan bahwa hukum pidana ekonomi diperlukan untuk menanggulangi tindak pidana korporasi. Untuk itu, tanggung jawab pidana korporasi sebagai person hukum perlu diatur secara khusus dalam KUHP di masa datang untuk mendayagunakan hukum pidana ekonomi sebagai sarana penanggulangan tindak pidana korporasi. Kebijakan pengaturan tanggung jawab pidana korporasi dalam KUHP merupakan implementasi tanggung jawab negara untuk melindungi segenap bangsa Indonesia dan seluruh tumpah darah Indonesia terhadap kerugian dan kerusakan akibat aktivitas korporasi di bidang ekonomi. 


\section{DAFTAR PUSTAKA}

Arifin, Sjamsul, Rizal A. Djaafara, dan Aida S. Budiman, 2008, Masyarakat Ekonomi Asean (MEA) 2015: Memperkuat Sinergi ASEAN di Tengah Kompetisi Global, Jakarta: Elex Media Komputindo.

Asean Secretariat, 2008, Asean Economic Community Blueprint, Jakarta: Asean Secretariat.

Asean Secretariat, 2008, Charter of The Association of Souteast Asian Nations, Jakarta: Asean Secretariat.

Box, Steven, 2003, Power Crime and Mystification, London-New York: Routledge.

Clarkson, C.M.V., Corporate Culpability, Web Journal of Current Legal Issues in association with Blackstone Press Ltd. <cmvc1@leicester.ac.uk> diakses 24 September 2014.

Declaration of ASEAN Concord II (Bali Concors II), http://www.asean.org/ news/item/declaration-of-aseanconcord-ii-bali-concord-ii, diakses 19 September 2014.

Friedmann, Wolfgang, 1949, Legal Theory, London: Stevens \& Sons Limited.

Geis, Gilbert, 2007, White-Collar Criminal: The Offenders in Business and Professions, New Jersey, Prentice Hall.

Gie, The Liang, 1996, Pengantar Filsafat Teknologi, Yogyakarta: Andi.

Gobert, James; Maurice Punch, 2003, Rethinking Corporate Crime, Dayton-Ohio-USA: Butterworths Lexis Nexis.
Hartley, Richard D., 2008, Corporate Crime: A Reference Handbook Contemporary World Issues, Santa Barbara-California: ABC-CLIO Inc.

Indonesia, Undang-Undang Dasar Negara Republik Indonesia Tahun 1945.

Indonesia, Undang-Undang Nomor 7/Drt. Tahun 1955 Tentang Pengusutan, Penuntutan dan Peradilan Tindak Pidana Ekonomi.

Lock, John (Edited by C. B. Macpherson), 1980, Second Treatise of Government, Cambridge: Hackett Publishing Company, Inc.

Muladi, 2002, Demokratisasi, Hak Asasi Manusia, dan Reformasi Hukum di Indonesia, Jakarta: The Habibie Center.

Persahi, 1989, Kerangka Landasan Pembangunan Hukum, Jakarta: Sinar Harapan.

Rahardjo, M. Dawam, 1985, Insan Kamil Konsepsi Manusia Menurut Islam, Jakarta: Grafiti Pers.

Ross, Edward Alsworth, 1907,Sin and Society: An Analysis of Latter-Day Iniquity, Boston-New York: Houghton Mifflin Company.

Sahetapy, J.E., 1994, Kejahatan Korporasi, Bandung: Eresco.

Salinger, Lawrence M. (Editor), 2005, Encyclopedia of White-collar and Corporate Crime Vol 1, California: Sage Publications Ltd.

Soemitro, Ronny Haitijo, 1984, Permasalahan Hukum Di Dalam Masyarakat, Bandung: Alumni.

Sudarto, 1986, Hukum dan Hukum Pidana, Bandung: Alumni.

Hamzah Hatrik, Liberalisasi Masyarakat Ekonomi ASEAN 2015: Apakah Kita Perlu Hukum Pidana Ekonomi? (Liberalization AEC 2015: Do We Need Economic Criminal Law?) 
Sutherland, Edwin Hardlin and Donald Ray Cresswy, Criminologi, Tenth Edition, 1978, Philadelphia-New York-San Jose-Toronto: J.B. Lippincott Company.

The Asean Declaration (Bangkok Declaration),http://www.asean.or g/news / item/the-aseandeclaration-bangkok-declaration, diakses 19 September 2014
United Nation Publication, 1986, Seventh United Nations Congress On The Prevention of Crime and The Treatment of Offenders, Millan, 26 August-6 September 1985, United Nations Report Prepared by Secretariat, New York.

Hamzah Hatrik, Liberalisasi Masyarakat Ekonomi ASEAN 2015: Apakah Kita Perlu Hukum Pidana Ekonomi? (Liberalization AEC 2015: Do We Need Economic Criminal Law?) 